\title{
Analysis of pharmaceutical assistance in the Taquari Valley, Rio Grande do Sul: profile of service users and access to medication
}

\author{
Carla Kauffmann ${ }^{1}$, Luciana Carvalho Fernandes ${ }^{1 *}$, Alícia Deitos ${ }^{2}$, Gabriela Laste ${ }^{3}$, Graziela \\ Heberlé1, Luís César de Castro ${ }^{1}$, Iraci Lucena da Silva Torres ${ }^{4}$
}

\begin{abstract}
${ }^{1}$ Centro de Ciências Biológicas e da Saúde, Centro Universitário-UNIVATES, ${ }^{2}$ Curso de Farmácia, Centro UniversitárioUNIVATES, ${ }^{3}$ Curso de Enfermagem, Centro Universitário UNIVATES, ${ }^{4}$ Departamento de Farmacologia, Instituto de Ciências
\end{abstract} Básicas da Saúde, Universidade Federal do Rio Grande do Sul

\begin{abstract}
Pharmaceutical assistance concerns actions developed by the pharmacist and other professionals with the purpose of promoting, protecting and restoring health. Medications are an essential tool in this process that focuses on the access to, and the rational use of, drugs. This study is aimed at evaluating the Pharmaceutical Assistance provided by Municipal Health Offices in the Taquari Valley, Rio Grande do Sul. For this purpose, 2,794 users of public pharmacies were interviewed and data was analyzed using descriptive statistics. The users of the public pharmacies were mainly female and individuals with low educational level and income. On average, 2.41 drugs were prescribed per medical prescription and 1.72 of these were procured. Out of the total medicines prescribed, $76.5 \%$ were listed in the municipal standard drug list (SDL). Medication was prescribed by its generic name in $81.8 \%$ of the prescriptions. Antibiotics and injections were prescribed in $11.9 \%$ and $4.0 \%$ of the prescriptions, respectively. Users' access to information is partial, which can impair adherence to the treatment. Thus, it is possible to conclude that review of the service is necessary for it to be effective.
\end{abstract}

Uniterms: Pharmaceutical assistance. Unified Health System. Medicines/rational use. Medicines/ prescription indicators.

\begin{abstract}
AAssistência Farmacêutica se preocupa com ações desenvolvidas pelo farmacêutico ou outros profissionais com o propósito de promover, proteger e restaurar a saúde. Medicamentos são ferramentas essenciais nesse processo, que se concentra no acesso e no uso racional de fármacos. Este estudo objetivou a avaliação da Assitência Farmacêutica suprida pela Secretaria Municipal da Saúde no Vale do Taquari, no Rio Grande do Sul. Com esse propósito, 2.794 usuários das farmácias públicas foram entrevistados e analisaram-se os dados usando estatística descritiva. Os usuários das farmácias públicas eram, principalmente, mulheres e indivíduos com baixo nível educacional e financeiro. Na média, 2,41 fármacos eram prescritos por prescrição médica e 1,72 destes foram obtidos. Do total de medicamentos prescritos, 76,5\% estava inscritos na lista de medicamentos padrão do município (SDL). A medicação foi prescrita pelo nome genérico em $81,8 \%$ dos casos. Antibióticos e injeções foram prescritas em 11,9\% e 4,0\% das prescrições, respectivamente. O acesso dos usuários à informação é parcial, o que pode prejudicar a adesão ao tratamento. Dessa forma, é possível concluir que a revisão do serviço é necessária para que seja eficaz.
\end{abstract}

Unitermos: Assistência farmacêutica. Sistema Único de Saúde. Medicamentos/uso racional. Medicamentos/indicadores de prescrição.

\section{INTRODUCTION}

The network of primary health care units, to which

\footnotetext{
*Correspondence: L. Carvalho Fernandes. Curso de Farmácia - UNIVATES, Centro Universitário, Centro de Ciências Biológicas e da Saúde, Rua Avelino Tallini, 171- Bairro Universitário, 95900000 - Lajeado - RS, Brasil. E-mail: lufernandes@univates.br
}

the municipal public pharmacies belong, account for the locations where most of the population seeks assistance (66.5\%) (Ribeiro et al., 2006). Therefore, a structured service of pharmaceutical assistance in these facilities is essential in ensuring access to medication and information, while contributing to an increase in health quality standards of the population. 
The Unified Health System (SUS) ensures access to medication based on the patient's rights to full execution of therapeutic assistance, including pharmaceutical assistance (Brazil, 1990). The latter is defined as "the group of activities related to medication, aimed at supporting the health practices required by a community. It involves medication provision, storage and quality control, therapeutic safety and efficacy of the medication, follow-up and assessment of its use, the acquisition and dissemination of information about medication, and the constant education of health care professionals, patients and the community in order to guarantee the rational use of medication." (Brasil, 1998).

In a bid to achieve qualification of primary health care, the National Policy of Pharmaceutical Assistance was instituted, by means of Resolution No. 338 (May 6, 2004), aimed at ensuring the principles of universality, equity and integrality, a constituent part of the National Health Policy. In this context, the objective of Pharmaceutical Assistance is ensuring the availability and rational use of medication as a tool to achieve universality, equity and integrality in the Unified Health System (SUS).

Medication has a relevant role in the restoration and maintenance of health (Girotto, Silva, 2006), whereby its rational use contributes to the quality of health services. On the other hand, its inappropriate or unadvised use may harm the user as well as society.

The counseling provided to the patient when medication is dispensed by the pharmacist is essential to promote its rational use and overall treatment. Research has demonstrated that patients are widely receptive to pharmaceutical counseling (Paulo, Zanini, 1997; Rantucci, 1998). The role of the pharmacist in the Pharmaceutical Assistance includes (besides guidance and education on health) the selection, supply schedule, purchase, storage, distribution and usage of medications (Brasil, 2001).

The assessment of Pharmaceutical Assistance quality allows the generation of data that may contribute to optimizing the investment of generally scarce financial resources. Furthermore, the gathered data may serve to guide actions resulting in the prevention of problems related to pharmacotherapy, thus reducing the number of medical appointments derived from the prescribing cascade (Rochon, Gurwitz, 1997). The appropriate implementation of this assessment will provide information that may support the restructuring and qualification of services performed by the health system, leading to an increase in patients' quality of life, as well as contributing to the knowledge of rational use of medications. Hence, this study aimed to evaluate the Pharmaceutical Assistance provided by $\mathrm{Mu}-$ nicipal Health Offices in the Taquari Valley, Rio Grande do Sul State.

\section{MATERIAL AND METHODS}

This study is part of the research project called Evaluation of the Pharmaceutical Assistance in the Unified Health System (SUS) in the Taquari Valley, Rio Grande do Sul State, a population-based cross-sectional study intended to better understand the structure of Pharmaceutical Assistance in the cities that constitute the Taquari Valley, as well as its interface with the system users.

Taquari Valley is comprised of 36 cities, located in the central area of the state of Rio Grande do Sul, with a total population of 316,714 inhabitants (BDR, 2008). The target population of the study was users of public pharmacies in these cities. The number of participants was established by the saturation sampling process. This means of determining the sample size is based on observation of repetition in the obtained answers, i.e., up to the point where collected data no longer presents variety for the subject on which the research is focused. Thus, the sample size is determined by the researcher, who evaluates the relevance of proceeding with the collection of data. (Bauer, Gaskell, 2002).

The following criteria were used for screening the participants for inclusion in this study: 18 years of age or older, approached immediately after being assisted at the pharmacy (regardless of whether or not they had access to the medication), and their willingness to take part in the study. Criteria for exclusion included the following: refusal from the administrator to include their city in the research; failure of the city administration to provide the required information (REMUME list); or the unwillingness of the user to participate in the study. The gathering of data was conducted from January through October, 2007.

A structured, pre-codified and previously tested three-part questionnaire was used to conduct the data collection. The first part included information related to the profile of the public pharmacy user: gender, age, family income, occupation and frequency of service use. The second involved information regarding the medical prescription: number of drugs per prescription, and how many of these were obtained through the Primary Health Care Unit. The third part of the questionnaire consisted of questions related to the information received about the prescribed medication: what medication was prescribed, its indication, dosage, storage instructions, adverse reactions and other information regarding its rational use (such as non-supervised discontinuation of treatment, access to documentation, doubts about the medication, indication of non-pharmacological treatment and procedure in case of medication leftover). 
To evaluate access to medication, municipal Standardized Drug Lists (SDL) were used. The prescribing indicators recommended by the World Health Organization (WHO) (1993) were also applied: mean number of medications per prescription, percentage of medications prescribed with their generic names, percentage of medications from the SDL, and percentage of antibiotics and injection drugs prescribed.

To evaluate patient awareness about the prescribed medications, the following ratings were considered: $a w a-$ re, partially aware or unaware. For each variable concerning awareness (indication, time for the medication to take effect and dosage) the whole of prescribed medications for each user was assessed. Thus, in the event that patients knew the variables for all the prescribed medications, he or she was rated as aware. In cases where the patient knew the variables for part of the prescribed medications, he or she was rated as partially aware and when the patient did not know the variables for any of the medications, he or she was rated as unaware.

The gathering of data was performed by a trained and supervised team, composed of twelve pharmacy and nursing students from the UNIVATES University Center.

The data were analyzed by the program EPI-INFO (version 3.3.2, 2005) and by the program SPSS (version $8.0,1998)$. The data analysis plan included a descriptive analysis by means of frequency distribution for the variables and their stratification according to the size of the city examined. The cities were divided into four groups regarding their population: cities with fewer than 10,000 inhabitants, 10,000 to 19,999 inhabitants, 20,000 to 29,999 inhabitants, and cities with more than 30,000 inhabitants.

In order to ensure confidentiality, minimum risk and discomfort as well as the maximization of benefits, all the users who agreed to participate in the study signed the Term of Free and Informed Consent (TFIC). The protocol complied with the conditions established by Resolution 196/96 of the National Health Council (NHC) and was approved by the Ethics Committee of the UNIVATES University Center (Resolution COEP no. 17/2006).

\section{RESULTS}

\section{Sample characterization}

Taquari Valley consists of 36 cities; 28 having participated in the research, three having expressed refusal to participate, and five having been excluded from the study for failure to supply the municipal Standardized Drug List. In order to simplify the analysis, the cities were grouped according to their population, so that 21 cities $(n=765$ users) formed the population group with fewer than 10,000 inhabitants. Three cities ( $\mathrm{n}=517$ users) comprised the group with population between 10,000 and 19,999 inhabitants, three cities ( $\mathrm{n}=848$ users) formed the group with population between 20,000 and 29,999 inhabitants, and one city had a population of more than 30,000 inhabitants ( $\mathrm{n}=664$ users). Nevertheless, it is important to highlight the fact that among the analyzed cities, only six (21.4\%) had a professional pharmacist running the pharmacy of the Primary Health Care Unit.

\section{Socio-demographic profile of users}

The variables analyzed were gender, age group, educational level, household income, occupation, and housing (rural or urban areas). Table 1 presents the overall data, including the valley and city groups.

Within the analyzed population sample, there is a prevalence of women $(67.1 \%)$, individuals under 50 years of age $(54.1 \%)$ and people with incomplete elementary education $(63.1 \%)$. These characteristics are consistent with those observed in other studies conducted among users of the Unified Health System - SUS (Colombo et al., 2004; Ribeiro et al, 2006; Paniz et al., 2008). In addition, this population lives predominantly in urban areas (75.4\%)

Regarding users' occupation, it was observed that most of this population is out of the job market (62.3\%), namely retirees or welfare beneficiaries, unemployed workers and other individuals who do not have an activity outside the household. However, it is important to draw attention to the fact that only $23.8 \%$ of the population analyzed is engaged in the formal job market. Another peculiar characteristic is the prevalence of retirees and welfare beneficiaries (40.8\%) in cities with fewer than 10,000 inhabitants and the consequent lower number of individuals engaged in the formal job market (15.0\%), which can be explained by the concentration of job opportunities in the central cities of the Valley. The monthly household income of most of this population is up to three minimum wages $(82.5 \%)$.

\section{Access to medication}

The number of medications per prescription ranged from 1-12, with a mean number of 2.41 drugs per medical prescription. On average, every patient had access to 1.72 medications ( 0 to 12 ) with regard to their prescription (Table II). The majority of the users $(59.2 \%)$ had their prescription needs completely met by the municipal pharmacies, whereas $27.9 \%$ of the users had their prescriptions 
TABLE I - Socio-demographic profile of users of Pharmacies within the Primary Health Care Units (UBS) in the Taquari Valley RS State ( $=2794$ - Taquari Valley)

\begin{tabular}{|c|c|c|c|c|c|c|}
\hline \multirow[t]{2}{*}{ VARIABLES } & & \multicolumn{4}{|c|}{ POPULATION (inhabitants) } & \multirow{2}{*}{$\begin{array}{l}\text { TAQUARI } \\
\text { VALLEY }\end{array}$} \\
\hline & & $<10,000$ & $10,000-19,999$ & $20,000-29,999$ & $>30,000$ & \\
\hline \multirow[t]{2}{*}{ GENDER } & Male & $37.0 \%$ & $32.9 \%$ & $31.7 \%$ & $29.8 \%$ & $32.9 \%$ \\
\hline & Female & $63.0 \%$ & $67.1 \%$ & $68.3 \%$ & $70.2 \%$ & $67.1 \%$ \\
\hline \multirow{7}{*}{$\begin{array}{l}\text { AGE GROUP } \\
\text { (years) }\end{array}$} & $<20$ & $16.8 \%$ & $7.2 \%$ & $17.8 \%$ & $17.3 \%$ & $15.4 \%$ \\
\hline & $21-30$ & $9.7 \%$ & $11.0 \%$ & $11.7 \%$ & $10.1 \%$ & $10.6 \%$ \\
\hline & $31-40$ & $10.0 \%$ & $12.0 \%$ & $11.5 \%$ & $14.0 \%$ & $11.7 \%$ \\
\hline & $41-50$ & $11.8 \%$ & $20.7 \%$ & $16.5 \%$ & $18.2 \%$ & $16.4 \%$ \\
\hline & $51-60$ & $17.3 \%$ & $19.5 \%$ & $19.1 \%$ & $17.6 \%$ & $18.3 \%$ \\
\hline & $61-70$ & $19.5 \%$ & $17.2 \%$ & $15.3 \%$ & $13.9 \%$ & $16.5 \%$ \\
\hline & $>71$ & $14.9 \%$ & $12.4 \%$ & $8.1 \%$ & $8.9 \%$ & $11.1 \%$ \\
\hline \multirow{8}{*}{$\begin{array}{l}\text { EDUCATIONAL } \\
\text { LEVEL }\end{array}$} & Illiterate & $6.8 \%$ & $2.5 \%$ & $6.5 \%$ & $5.7 \%$ & $5.7 \%$ \\
\hline & Incomplete elementary education & $67.2 \%$ & $71.0 \%$ & $58.4 \%$ & $58.4 \%$ & $63.1 \%$ \\
\hline & Complete elementary education & $7.1 \%$ & $4.4 \%$ & $6.5 \%$ & $8.4 \%$ & $6.7 \%$ \\
\hline & Incomplete secondary education & $2.6 \%$ & $5.0 \%$ & $7.7 \%$ & $5.1 \%$ & $5.2 \%$ \\
\hline & High school diploma & $7,3 \%$ & $11.0 \%$ & $9.3 \%$ & $10.7 \%$ & $9.4 \%$ \\
\hline & Incomplete college & $0.8 \%$ & $0.8 \%$ & $1.2 \%$ & $0.9 \%$ & $0.9 \%$ \\
\hline & College degree & $1.0 \%$ & $1.0 \%$ & $0.6 \%$ & $1.1 \%$ & $0.9 \%$ \\
\hline & Does not know/has not answered & $7.2 \%$ & $4,3 \%$ & $9.8 \%$ & $9.7 \%$ & $8.1 \%$ \\
\hline \multirow[t]{5}{*}{ OCCUPATION } & Formal employment & $15.0 \%$ & $29.8 \%$ & $22.9 \%$ & $31.1 \%$ & $23.8 \%$ \\
\hline & Informal employment & $22.9 \%$ & $11.5 \%$ & $13.1 \%$ & $6.1 \%$ & $13.9 \%$ \\
\hline & Unemployed & $1.0 \%$ & $1.9 \%$ & $3.3 \%$ & $4.5 \%$ & $2.7 \%$ \\
\hline & Does not work & $20.3 \%$ & $23.2 \%$ & $31.7 \%$ & $34.0 \%$ & $27.6 \%$ \\
\hline & Retired or welfare beneficiary & $40.8 \%$ & $33.6 \%$ & $29.0 \%$ & $24.3 \%$ & $32.0 \%$ \\
\hline \multirow{6}{*}{$\begin{array}{l}\text { HOUSEHOLD } \\
\text { INCOME } \\
\text { PER MONTH* }\end{array}$} & $<1$ minimum wage & $6.4 \%$ & $2.3 \%$ & $4.6 \%$ & $3.6 \%$ & $4.2 \%$ \\
\hline & $1-3$ minimum wages & $77.3 \%$ & $77.6 \%$ & $81.7 \%$ & $76.5 \%$ & $78.3 \%$ \\
\hline & 4 - 5 minimum wages & $12.9 \%$ & $14.5 \%$ & $9.4 \%$ & $15.4 \%$ & $13.1 \%$ \\
\hline & $6-10$ minimum wages & $2.2 \%$ & $4.1 \%$ & $1.8 \%$ & $2.6 \%$ & $2.7 \%$ \\
\hline & $>10$ minimum wages & $0.3 \%$ & $0.2 \%$ & $0.8 \%$ & $0.8 \%$ & $0.5 \%$ \\
\hline & Does not know/has not answered & $0.9 \%$ & $1.3 \%$ & $1.7 \%$ & $1.1 \%$ & $1.2 \%$ \\
\hline \multirow[t]{2}{*}{ HOUSING } & Rural area & $57.5 \%$ & $29.0 \%$ & $13.3 \%$ & $0.9 \%$ & $25.4 \%$ \\
\hline & Urban area & $42.5 \%$ & $71.0 \%$ & $86.7 \%$ & $99.1 \%$ & $74.6 \%$ \\
\hline
\end{tabular}

* national minimum wage (equivalent to $\mathrm{R} \$ 350.00$ when research was conducted)

partially supplied. Only $12.9 \%$ of the patients did not have access to any of their prescribed medications at the municipal pharmacies. (Table II).

The prescriptions for these patients were assessed according to criteria of the WHO, thus $76.5 \%$ of the drugs prescribed were part of the Municipal Standardized Dug List (SDL) of the analyzed cities (ranging between $72.4 \%$ and $82.2 \%$ ). The use of generic brands occurred in the prescription of $81.8 \%$ of the medications, varying between 73.4 and $90.4 \%$ among the evaluated city groups. Antibiotics were found in $11.9 \%$ of the prescriptions, varying between 8.1 and $18.6 \%$ depending on the city group analyzed. Prescriptions for injection drugs were issued to $4.0 \%$ of the users, varying between 1.7 and $6.4 \%$ among the city groups (Table II).

Considering access to medication, it was found that in most cases (90.9\%), the medications supplied to users from the study sample were part of the municipal SDL. 
TABLE II - Assessment of prescribing indicators recommended by WHO in prescriptions supplied at Pharmacies within the Primary Health Care Units (UBS) in the Taquari Valley - RS State ( $=2794$ - Taquari Valley)

\begin{tabular}{|c|c|c|c|c|c|}
\hline \multirow[t]{2}{*}{ VARIABLES } & \multicolumn{4}{|c|}{ POPULATION (inhabitants) } & \multirow{2}{*}{$\begin{array}{l}\text { TAQUARI } \\
\text { VALLEY }\end{array}$} \\
\hline & $<10,000$ & $10,000-19,999$ & $20,000-29,999$ & $>30,000$ & \\
\hline Mean number of medications per prescription & 2.54 & 2.33 & 2.48 & 2.25 & 2.41 \\
\hline $\begin{array}{l}\text { Percentage of medications prescribed from the } \\
\text { municipal Standard Drug List (SDL) }\end{array}$ & $72.4 \%$ & $82.2 \%$ & $76.5 \%$ & $77.2 \%$ & $76.5 \%$ \\
\hline $\begin{array}{l}\text { Percentage of medications prescribed with their } \\
\text { generic names (Common Brazilian Denomination) }\end{array}$ & $79.9 \%$ & $80.2 \%$ & $73.4 \%$ & $90.4 \%$ & $81.8 \%$ \\
\hline Percentage of antibiotics & $11.4 \%$ & $8.1 \%$ & $18.6 \%$ & $9.6 \%$ & $11.9 \%$ \\
\hline Percentage of injection drugs & $3.8 \%$ & $3.9 \%$ & $6.4 \%$ & $1.7 \%$ & $4.0 \%$ \\
\hline Mean number of medications obtained & 1.89 & 1.56 & 1.68 & 1.67 & 1.72 \\
\hline $\begin{array}{l}\text { Percentage of medications obtained from the } \\
\text { municipal SDL }\end{array}$ & $92.3 \%$ & $92.3 \%$ & $86.7 \%$ & $92.9 \%$ & $90.9 \%$ \\
\hline $\begin{array}{l}\text { Percentage of medications obtained that are not } \\
\text { part of the municipal SDL }\end{array}$ & $7.7 \%$ & $7.7 \%$ & $13.3 \%$ & $7.1 \%$ & $9.1 \%$ \\
\hline $\begin{array}{l}\text { Percentage of missing medications from the } \\
\text { municipal SDL }\end{array}$ & $44.7 \%$ & $65.6 \%$ & $56.6 \%$ & $32.1 \%$ & $50.4 \%$ \\
\hline $\begin{array}{l}\text { Percentage of missing medications that are not part } \\
\text { of the municipal SDL }\end{array}$ & $55.3 \%$ & $34.4 \%$ & $43.4 \%$ & $67.9 \%$ & $49.6 \%$ \\
\hline \multirow{3}{*}{$\begin{array}{ll}\text { Access } & \text { Total } \\
& \text { Partial } \\
& \text { None }\end{array}$} & $62.8 \%$ & $54.4 \%$ & $56.3 \%$ & $62.5 \%$ & $59.2 \%$ \\
\hline & $28.6 \%$ & $25.9 \%$ & $30.3 \%$ & $25.6 \%$ & $27.9 \%$ \\
\hline & $8.6 \%$ & $19.7 \%$ & $13.4 \%$ & $11.9 \%$ & $12.9 \%$ \\
\hline
\end{tabular}

However, in cases of inaccessibility, it was found that $50.4 \%$ of the medications were part of the SDL (Table II). The users reported that, in cases where the medication was not available at the UBS pharmacy, they either purchased it $(87.1 \%)$, awaited the medication stock replenishment $(2.7 \%)$, did not use the medication $(4.6 \%)$ or took other measures $(5.6 \%)$.

The prescribed medications overall are continuoususe drugs (62.6\%). In the analyzed cities, the distribution of medication for treatment of chronic diseases was for a 30-day period. These data therefore support the findings that $69.3 \%$ of the population of the study returns to the UBS Pharmacy at least once a month, whereas the remaining users do so less often, or only when necessary $(30.7 \%)$.

\section{Access to information}

Most of the users reported being given information about the medications $(70.7 \%)$ and reported having no doubts $(91.3 \%)$. When questioned about the information obtained, the users reported that it concerned dosage $(68.2 \%)$, indication $(12.2 \%)$, indication and dosage (11.4\%), adverse reactions $(2.4 \%)$, importance of treat- ment engagement $(2.3 \%)$, or other $(3.5 \%)$. However, the vast majority of the population analyzed reported neither obtaining information about storage of the medications $(73.4 \%)$, nor having received information documentation (87.5\%) (Table III).

The small proportion of the analyzed population that mentioned having doubts or concerns, reported that these were related to the efficacy of the medications (19.4\%), their safety (43.9\%), the lack of access to the medication $(10.1 \%)$, the difference between generic and brand-name drugs $(2.9 \%)$ or other $(23.7 \%)$.

Patient awareness about medication was assessed and the results are presented in Table IV. The sample population, overall, was aware of the indication $(81.1 \%)$ and dosage $(81.7 \%)$ of the prescribed medications. However, only a minority of users were aware of the time it takes for the medication to take effect (1.1\%). The study also found that $54.5 \%$ of the users store the medications in inappropriate locations.

The study also shows that $42.8 \%$ of the users reported that there was no leftover medication. However, other users mentioned keeping the remaining medication $(21.2 \%)$, returning it to the pharmacy $(23.2 \%)$, donating it to other people $(0.5 \%)$ or discarding it $(12.3 \%)$. 
TABLE III - Access to information about prescribed medications among users of Pharmacies within the UBS in the Taquari Valley, RS State $(\mathrm{N}=2794-$ Taquari Valley)

\begin{tabular}{lcccccc}
\hline VARIABLES & & \multicolumn{3}{c}{ POPULATION (inhabitants) } & TAQUARI \\
\cline { 2 - 5 } & & $<10000$ & $10000-19999$ & $20000-29999$ & $>30000$ & VALLEY \\
\hline Information about the medications & YES & $68.4 \%$ & $83.2 \%$ & $75.5 \%$ & $57.5 \%$ & $70.7 \%$ \\
& NO & $31.6 \%$ & $16.8 \%$ & $24.5 \%$ & $42.5 \%$ & $29.3 \%$ \\
Information about storage of & YES & $31.1 \%$ & $17.0 \%$ & $21.9 \%$ & $34.6 \%$ & $26.6 \%$ \\
medications & NO & $68.9 \%$ & $83.0 \%$ & $78.1 \%$ & $65.4 \%$ & $73.4 \%$ \\
Access to documentation & YES & $24.3 \%$ & $11.0 \%$ & $6.5 \%$ & $7.8 \%$ & $12.5 \%$ \\
\multirow{2}{*}{ Doubts or concerns } & NO & $75.7 \%$ & $89.0 \%$ & $93.5 \%$ & $92.2 \%$ & $87.5 \%$ \\
& YES & $9.4 \%$ & $5.6 \%$ & $11.0 \%$ & $7.2 \%$ & $8.7 \%$ \\
& NO & $90.6 \%$ & $94.4 \%$ & $89.0 \%$ & $92.8 \%$ & $91.3 \%$ \\
\hline
\end{tabular}

TABLE IV - Assessment of patient awareness of prescribed medications among users of pharmacies within the Primary Health Care Units (UBS) in the Taquari Valley - RS State $(\mathrm{N}=2794$ - Taquari Valley)

\begin{tabular}{llccccc}
\hline VARIABLES & & \multicolumn{3}{c}{ POPULATION (inhabitants) } & TAQUARI \\
\cline { 3 - 6 } INDICATION & aware & $88.0 \%$ & $84.7 \%$ & $72.5 \%$ & $81.3 \%$ & $81.1 \%$ \\
& partially aware & $8.5 \%$ & $8.5 \%$ & $20.8 \%$ & $9.8 \%$ & $12.5 \%$ \\
& unaware & $3.5 \%$ & $6.8 \%$ & $6.7 \%$ & $8.9 \%$ & $6.4 \%$ \\
\hline TIME FOR DRUG TO & aware & $0.5 \%$ & $2.1 \%$ & $0.7 \%$ & $1.4 \%$ & $1.1 \%$ \\
TAKE EFFECT & partially aware & $0.3 \%$ & $4.3 \%$ & $4.1 \%$ & $3.8 \%$ & $3.0 \%$ \\
& unaware & $99.2 \%$ & $93.6 \%$ & $95.2 \%$ & $94.8 \%$ & $95.9 \%$ \\
\hline DOSAGE & aware & $77.8 \%$ & $95.6 \%$ & $83.1 \%$ & $73.6 \%$ & $81.7 \%$ \\
& partially aware & $18.8 \%$ & $1.5 \%$ & $13.3 \%$ & $19.1 \%$ & $14.0 \%$ \\
& unaware & $3.4 \%$ & $2.9 \%$ & $3.6 \%$ & $7.3 \%$ & $4.3 \%$ \\
\hline STORAGE & appropriate & $49.0 \%$ & $45.9 \%$ & $46.2 \%$ & $40.2 \%$ & $45.5 \%$ \\
& inappropriate & $51.0 \%$ & $54.1 \%$ & $53.8 \%$ & $59.8 \%$ & $54.5 \%$ \\
\hline
\end{tabular}

Most users (95.2\%) believed it was important to use the medication. However, $14.9 \%$ of the population studied reported interrupting the treatment without medical supervision.

\section{DISCUSSION}

In the Taquari Valley, despite the fact that $59.2 \%$ of the population has access to the medication, there are discrepancies between the prescribed and standardized drugs (part of the municipal standard drug lists). In addition, there is some lack of patient awareness of pharmacotherapy. These findings, therefore, are factors that may compromise the rational use of medication.

Paniz et al (2008), assisted by the Project for Expansion and Consolidation of the Family Health, conducted a study that included adults (aged 30-64 years) and elderly (aged 65 years or more) in the South and Northeast regions of Brazil. This study about access to continuous-use medication for treatment of diabetes, high blood pressure and/or mental illnesses, found total access was observed in $81.2 \%$ of the cases, whereas partial access corresponded to $7.0 \%$ and no access was observed in $11.8 \%$ of the cases. In the Taquari Valley study, the users with total access corresponded to $59.2 \%$ of the sample. This lower score may be related to the way data were gathered, not limiting access to specific groups. In addition, Paniz et al conducted their study in areas assisted by the Family Health Program, therefore the areas had a higher level of social assistance.

Table IV presents data from studies conducted in Brazil assessing prescriptions according to the prescribing indicators recommended by the World Health Organiza- 
tion (WHO). In the Taquari Valley, the mean number of prescribed drugs (2.41) was higher than that recommended by the WHO and the findings of other studies (Colombo et al., 2004; Santos, Nitrini, 2004; Brasil, 2005; Naves, Silver, 2005; Girotto, Silva, 2006; Farias et al., 2007). The percentage of prescribed medications that are part of the municipal SDL in the area $(76.5 \%)$ exceeded the recommendations of the WHO. However, the figure was lower than the findings for other Brazilian regions in these other studies. Generic drug names were used in $81.8 \%$ of the analyzed prescriptions. This finding, although not ideal since legal recommendations are for $100 \%$ generic names in prescriptions within the primary health care facilities, is higher than the level observed in other Brazilian studies (Santos, Nitrini, 2004; Naves, Silver, 2005; Girotto, Silva, 2006), except those conducted by the Pan American Health Organization/World Health Organization (PAHO/WHO) (Brasil, 2005) and by Farias et al. (2007).

The proportion of antibiotics per prescription in the Taquari Valley (11.9\%) was lower than the WHO limit rate and lower than results found in other studies (Santos, Nitrini, 2004; Brazil, 2005; Naves, Silver, 2005; Girotto, Silva, 2006; Farias et al, 2007), with the exception of research performed in Blumenau, Santa Catarina, by Colombo et al (2004). In their study, the percentage corresponded to $12.5 \%$, a similar score to that observed in the Taquari Valley. The percentage of injection drugs per prescription within the analyzed region, as observed in the other studies was lower than that established by the World Health Organization.

Consequently, it can be reported that the quality of analyzed prescriptions, and the levels of injection drugs and antibiotics are within reasonable limits, thus contributing to the rational use of medication. However, some lack of access was found regarding the prescription of items from the municipal standard drug lists, and some non-compliance with the current legislation on use of the Common Brazilian Denomination (CBD) for prescriptions issued within the Unified Health System.

Comparison of the city groups of the Taquari Valley, reveals differences concerning the access to medication variables (percentage of prescribed medications from the municipal Standard Drug List (SDL), and missing medications per prescription). Colombo et al concluded that one of the possible causes for lack of access was related to the standardization of medication. In other words, the prescribed medications were not part of the municipal SDL of the analyzed city.

In cities with fewer than 10,000 inhabitants, a lower score for prescribed medications from the SDL can be observed $(72.4 \%)$. However, $92.3 \%$ of the obtained medication was part of the SDL. It is interesting to point out that only $7.7 \%$ of the unavailable medication was listed in the SDL. However, as a result of this inadequacy of the municipal SDL, it is observed that $55.3 \%$ of the missing medications were not part of this list. This reinforces the importance for each city of prescribing medications according to the current standardization, thus ensuring access to safe and efficient medications.

In cities with population between 10,000 and 19,999 inhabitants, a higher score of prescribed medications from the municipal SDL was found $(82.2 \%)$ with a consequent lower score of missing medications that are not part of the SDL (34.4\%). This inaccessibility cannot be attributed to

TABLE V - Assessment of prescribing indicators recommended by the WHO in studies conducted in Brazil

\begin{tabular}{|c|c|c|c|c|c|c|c|c|}
\hline VARIABLES & WHO & $\begin{array}{l}\text { Colombo } \\
\text { et al., } \\
2004\end{array}$ & $\begin{array}{l}\text { Santos and } \\
\text { Nitrini, } \\
2004\end{array}$ & $\begin{array}{l}\text { Brasil, } \\
2005\end{array}$ & $\begin{array}{l}\text { Naves and } \\
\text { Silver, } \\
2005\end{array}$ & $\begin{array}{l}\text { Girotto } \\
\text { and Silva, } \\
2006\end{array}$ & $\begin{array}{c}\text { Farias et } \\
a l ., \\
2007\end{array}$ & $\begin{array}{l}\text { TAQUARI } \\
\text { VALLEY }\end{array}$ \\
\hline $\begin{array}{l}\text { Mean number of medications } \\
\text { per prescription }\end{array}$ & $\begin{array}{c}2.0 \\
\text { or less }\end{array}$ & 1.8 & 2.2 & 2.3 & 2.3 & 2.0 & 1.5 & 2.41 \\
\hline $\begin{array}{l}\text { Percentage of medications prescribed } \\
\text { from the municipal SDL }\end{array}$ & $70 \%$ & $82.4 \%$ & $83.4 \%$ & $78.3 \%$ & $85.3 \%$ & $58.4 \%$ & $91.9 \%$ & $76.5 \%$ \\
\hline $\begin{array}{l}\text { Percentage of medications prescribed } \\
\text { with generic names (CBD) }\end{array}$ & $100 \% *$ & $\begin{array}{c}\text { not } \\
\text { collected } \\
\text { data }\end{array}$ & $30.6 \%$ & $84.2 \%$ & $73.2 \%$ & $70.2 \%$ & $84.2 \%$ & $81.8 \%$ \\
\hline Percentage of antibiotics & $\begin{array}{l}20 \% \\
\text { or less }\end{array}$ & $12.5 \%$ & $21.3 \%$ & $40.1 \%$ & $26.4 \%$ & $22.0 \%$ & $21.1 \%$ & $11.9 \%$ \\
\hline Percentage of injection drugs & $\begin{array}{l}10 \% \\
\text { or less }\end{array}$ & $8.1 \%$ & $8.3 \%$ & $7.9 \%$ & $7.5 \%$ & $7.0 \%$ & $1.1 \%$ & $4.0 \%$ \\
\hline
\end{tabular}

* Mandated by Brazilian legislation (Brazil, 1999). SOURCE: adapted from Farias et al., 2007. 
drug standardization alone, but also to other aspects related to the Pharmaceutical Assistance cycle, such as supply schedule and acquisition.

The cities with populations ranging between 20,000 and 29,999 inhabitants, on the other hand, are characterized by a higher percentage of obtained medications that are not in the municipal SDL (13.3\%) and a significant percentage of missing medications that belong to the list $(56.6 \%)$. These data point to a discrepancy between prescription, standardization and acquisition, given the fact that medications not part of the SDL are prescribed and therefore supplied, to the detriment of those that are standardized yet not available at the Primary Health Units.

In the one city with a population of more than 30,000 inhabitants, $77.2 \%$ of the prescribed medications and $92.9 \%$ of the obtained medications were part of the municipal SDL. Furthermore, this group is notable for displaying the lowest score of missing standardized medications (32.1\%). These findings allow us to infer that the observance of the municipal SDL increases the probability of access to medication. However, other steps in the cycle must be observed in order to ensure full pharmacotherapy to the user.

In relation to patient awareness about prescribed medication, the need for safe storage information is evident, since medication was being stored in inappropriate locations by $54.5 \%$ of the sample. It is also apparent that clear indication and dosage information was lacking for $18.9 \%$ and $18.3 \%$ of the users, respectively. These findings could be related to the fact that $73.4 \%$ of the sample did not have access to storage information, while $87.5 \%$ did not have access to explanatory documentation. Moreover, considering that $62.6 \%$ of the prescribed medications were continuous-use drugs, lack of patient awareness about correct storage (as well as indication, dosage and time for the drug to take effect), suggests flaws in the prescription and medication dispensing processes.

According to Silva et al. (2000), the absence of information constitutes one of the main reasons why $30 \%$ to $50 \%$ of patients do not use medications according to the prescription, and why many patients interrupt the treatment once they feel better. As spontaneously reported, $14.9 \%$ of the sample population admitted to interrupting the treatment without supervision, which may be a consequence of the previously mentioned procedural flaws.

Furthermore, it is important to stress that, among users who obtained information about their medication, only $2.4 \%$ were informed of potential adverse drug reactions (ADR). In addition, of the users who reported having doubts about pharmacotherapy, $43.9 \%$ were concerned about ADR. This information gap may cause the pres- cribing cascade, where the patient does not acknowledge their symptom as a probable ADR, seeks further medical assistance and gets a new prescription, thus being unnecessarily exposed to a new pharmacotherapy that might cause other ADRs.

Given the fact that most of the sampled population made use of continuous-use drugs, the lack of awareness of the previously mentioned concerns may cause problems in the pharmacotherapy. Moreover, the cohort that does not get their medication at the Municipal Pharmacies has a low household income, which hinders treatment engagement. Ultimately, in order that medication can have a rational use, and to ensure access, the patient needs to be educated about its use. This requires the involvement of city administrators, prescribing physicians, individuals in charge of medication dispensing processes as well as users of the Primary Health Care System. Therefore, this allows us to conclude that review of this service is vital, and that this action must involve health care workers and city administrators with a main goal being the training of Pharmaceutical Assistance to promote the rational use of medication.

\section{ACKNOWLEDGEMENTS}

We express our thanks for financial support from the Department of Science and Technology at the Secretariat of Science, Technology and Strategic Inputs of the Ministry of Health (DECIT/SCTIE/MS), from the National Council for Scientific and Technological Development (CNPq) and from UNIVATES University Center.

\section{REFFERENCES}

ARRAIS, P. S. D.; BARRETO M. L.; COELHO, H. L. L. Aspectos dos processos de prescrição e dispensação de medicamentos na percepção do paciente: estudo de base populacional em Fortaleza, Ceará, Brasil. Cad. Saúde Pública, v.23, p.927-937, 2007.

BAUER, M.; GASKELL, G. (Orgs.). Pesquisa qualitativa com texto, imagem e som. 2.ed. Petrópolis: Vozes, 2002. 516 p.

BDR - Banco de Dados Regionais do Centro Universitário UNIVATES. Avaiable at: <http://www.univates.br/>. Accessed on: 01 mar. 2008.

BRASIL. Lei Federal n.8.080, de 19 de setembro de 1990. Dispõe sobre as condições para a promoção, proteção e recuperação da saúde, a organização e o funcionamento dos serviços correspondentes e dá outras providências. Diário Oficial da União, Brasília, 20 set. 1990. Seção1, p.018055. 
BRASIL. Ministério da Saúde. Portaria GM n.3.916, 30 de outubro de 1998. Aprova a política nacional de medicamentos. Diário Oficial da União, Brasília, 10 nov. 1998. Seção1, p.18-22.

BRASIL. Lei 9787, de 10 de fevereiro de 1999. Altera a Lei n.6.360, de 23 de setembro de 1976, que dispõe sobre a vigilância sanitária, estabelece o medicamento genérico, dispõe sobre a utilização de nomes genéricos em produtos farmacêuticos e dá outras providências. Diário Oficial da União, Brasília, 11 fev. 1999. Seção1, p.1.

BRASIL. Ministério da Saúde. Secretaria de Políticas de Saúde, Departamento de Atenção Básica, Gerência Técnica de Assistência Farmacêutica. Assistência farmacêutica: instruções técnicas para a sua organização. Brasília, 2001. $114 \mathrm{p}$.

BRASIL. Ministério da Saúde. Conselho Nacional de Saúde. Resolução n.338, de 06 de maio de 2004. Aprova a política nacional de assistência farmacêutica. Avaiable at: $<$ http:// portal.saude.gov.br/portal/arquivos/pdf/resol_cns338.pdf $>$. Accessed on: 01 mar. 2008.

BRASIL. Ministério da Saúde; Organização Pan-Americana da Saúde; Organização Mundial da Saúde. Avaliação da assistência farmacêutica no Brasil: estrutura, processo e resultados. Brasília: Ministério da Saúde, 2005. 260 p.

COLOMBO, D.; SANTA HELENA, E. T.; AGOSTINHO, A. C. M. G.; DIDJURGEIT, J. S. M. A. Padrão de prescrição de medicamentos nas Unidades de Programa de Saúde da Família de Blumenau. Rev. Bras. Ciênc. Farm., v.40, p.549-558, 2004.

FARIAS, A. D.; CARDOSO, M. A. A.; MEDEIROS, A. C. D.; BELÉM, L. F.; SIMÕES, M. O. S. Indicadores de prescrição médica nas unidades básicas de Saúde da Família no município de Campina Grande, PB. Rev. Bras. Epidemiol., v.10, p.149-156, 2007.

GIROTTO, E.; SILVA, P. V. A prescrição de medicamentos em um município do Norte do Paraná. Rev. Bras. Epidemiol., v.9, p.226-234, 2006.
NAVES, J. O. S.; SILVER, L. D. Avaliação da assistência farmacêutica na atenção primaria no Distrito Federal. Rev. Saúde Pública, v.39, p.223-230, 2005.

ORGANIZACIÓN MUNDIAL DE LA SALUD. Como investigar el uso de medicamentos en los servicios de salud. Indicadores seleccionados del uso de medicamentos. Ginebra: OMS, 1993. 100 p. (DAP. 93.1).

PANIZ, V. M. V.; FASSA, A. G.; FACCHINI, L. A.; BERTOLDI, A. D.; PICCINI, R. X.; TOMASI, E.; THUMÉ, E.; SILVEIRA, D. S.; SIQUEIRA, F. V.; RODRIGUES, M. A. Acesso a medicamentos de uso contínuo em adultos e idosos nas regiões Sul e Nordeste do Brasil. Cad. Saúde Pública, v.24, p.267-280, 2008.

PAULO, L. G.; ZANINI, A. C. Compliance - sobre o encontro paciente-médico. São Roque: Ipex Comercial, 1997. 102 p.

RANTUCCI, M. J. Guía de consejo del farmacéutico al paciente. Barcelona: Masson, 1998. 281 p.

RIBEIRO, M. C. S. A.; BARATA, R. B.; ALMEIDA, M. F.; SILVA, Z. P. Perfil sociodemográfico e padrão de utilização de serviços de saúde para usuários e não-usuários do SUS - PNAD 2003. Ciênc. Saúde Coletiva, v.11, p.1011-1022, 2006.

ROCHON, P. A.; GURWITZ, J. H. Optimising drug treatment for elderly people: the prescribing cascade. Brit. Med.l J., v.315, p.1096-1099, 1997.

SANTOS, V.; NITRINI, S. M. O. Indicadores do uso de medicamentos prescritos e de assistência ao paciente de serviços de saúde. Rev. Saúde Pública, v.38, p.819-826, 2004.

SILVA, T.; SCHENKEL, E. P.; MENGUE, S. S. Nível de informação a respeito de medicamentos prescritos a pacientes ambulatoriais de hospital universitário. Cad. Saúde Pública, v.16, supl.2, p.449-455, 2000.

Received for publication on $23^{\text {th }}$ October 2008 . Accepted for publication on $24^{\text {th }}$ April 2009. 
